\title{
The influence of defoliation and nitrogen on the regrowth of Rhodes grass (Chloris gayana Kunth). 2. Etiolated growth and non-structural carbohydrate, total- $\mathrm{N}$ and nitrate- $\mathrm{N}$ content
}

\author{
A. Dovrat ${ }^{1}$, B. Deinum² and J. G. P. Dirven ${ }^{2}$ \\ 1 Department of Field and Vegetable Crops, Faculty of Agriculture, Hebrew Univer- \\ sity, Rehovot, Israel \\ 2 Department of Field Crops and Grassland Husbandry, Agricultural University, \\ Wageningen, the Netherlands
}

Received: 21 December 1971

\section{Summary}

Results of chemical analyses are presented of plant material obtained from pot experiments with 'Common' Rhodes grass of which data of dry-matter production have been rcported in our previous paper. The amount of etiolated growth made in darkness following cutting was used as an estimate of the energy reserve available for initial regrowth.

Plants fertilized with the high level of $\mathrm{N}$ contained on the average about $30 \%$ less carbohydrate in the stubble and in the roots than those supplied with the low level of $\mathrm{N}$. The carbohydrate content of 28-day-old plants was generally lower than that of 14-dayold plants. The amount of etiolated growth was positively correlated with the carbohydrate level in the roots and in the stubble. The percentage of tillers regrowing in darkness linearly increased up to about 60 with the increase of the amount of etiolated growth.

The total-N content of shoots and of stubble almost duobled as the result of high-N application compared with low N. Nitrate amounted to about $12 \%$ of the total-N content of the herbage of low-N plants whereas it was as high as $470 \%$ of that of the high-N plants. The nitrate content of shoots, of stubble and of roots was negatively correlated with the carbohydrate level of each of these fractions.

The overall difference of carbohydrate level between shoots, stubble and roots was relatively small. It was concluded that Rhodes grass has a limited capacity to accumulate reserve material when grown under conditions which favour rapid growth.

\section{Introduction}

The level of non-structural carbohydrate in plant tissue is often thought to reflect the metabolic energy balance in herbaceous plants. Thus Davidson and Milthorpe (1965, 1966), Alberda (1966), Blaser et al. (1966) and other workers, mostly experimenting with cool-season grasses, concluded that any one, or a combination of environmental factors that stimulate or retard growth relatively more than net photosynthesis, cause decreases or increases of carbohydrate in plant tissue. This principle is often supported 
by data which relate the rate of initial regrowth after defoliation with the non-structural carbohydrate content of shoots, stubble or roots.

In our previous paper (Dovrat et al., 1971) data have been presented of changes which occurred in the distribution of dry matter and tillering pattern following different defoliation treatments and different rates of $\mathrm{N}$ to Rhodes grass. In this paper results are reported of the chemical analyses done with this plant material. The level of non-structural carbohydrates, total- $\mathrm{N}$ and nitrate- $\mathrm{N}$ in the various plant fractions are considered as parameters of regrowth potential.

\section{Experimental}

\section{Materials and methods}

Chemical analyses were carried out of samples obtained from Rhodes grass cv. 'Common' which was grown in pots and clipped every 14 or 28 days over a period of 56 days (Dovrat et al., 1971). Two rates of $\mathrm{N}$ were applied as ammonium nitrate denoted low $\mathrm{N}$ (total $1.43 \mathrm{meq} / 100 \mathrm{~g}$ soil) or high $\mathrm{N}$ (total $8.29 \mathrm{meq} / 100 \mathrm{~g}$ soil). Identical treatments were applied in 2 separate trials but initial age of seedlings differed.

On every clipping date 5 replicate pots of each treatment were removed and harvested. The contents were divided into the following 3 fractions: shoots, $6-\mathrm{cm}$ stubble and roots. The roots were carefully washed over a sieve to remove adhering soil and dead plant material. The fractions were immediately dried in a forced-draft oven at $70{ }^{\circ} \mathrm{C}$, weighed, ground and stored. The material obtained from replicate treatments was carefully mixed to form one sample for chemical analysis, each done in duplicate. Analysis of variance of the data was done for a completely randomized design in which clipping dates were substituted for replications ignoring a possible treatment $\times$ clipping interaction.

An additional set of 5 replicate pots of each treatment was also removed on each clipping date. The shoots were clipped $6 \mathrm{~cm}$ above ground level and placed in an aerated dark chamber at $30^{\circ} \mathrm{C}$. The moisture content of the soil in each pot was kept adequate throughout the period of regrowth. One harvest was made as soon as etiolated growth had ceased, usually 5-6 days following clipping. The number of regrowing tillers and the shoot weight were determined. Etiolated growth was expressed in $\mathrm{mg}$ dry weight per pot.

\section{Chemical analyses}

\section{Non-structural carbohydrates}

Water-soluble-carbohydrate content was determined by $\mathrm{Cu}$ reduction according to van der Plank (1936) as revised by Bosman (1953). The extraction of carbohydrates from plant material with water (Smith et al., 1964) was considered appropriate since starch was not found to be present following analyses done by Gaillard (personal communication) and by Dovrat and Cohen (1970). Hunter et al. (1970) also found about $1 \%$ of starch in the shoots of Rhodes grass which is $30-50 \%$ of nonstructural carbohydrates.

\section{Total and nitrate nitrogen}

The percentage of total- $\mathrm{N}$, including nitrate- $\mathrm{N}$, was determined according to Deys (1961) and that of nitrate- $\mathrm{N}$ with a nitrate ion activity electrode (Model 92-07, Orion Research, Cambridge, Mass,, USA). 


\section{Results}

\section{Non-structural-carbohydrate content}

The average carbohydrate level of shoots and stubble of identical treatments within each experiment was quite similar whereas that of roots was generally lower than of shoots and of stubble (Table 1). The level of high-N plants was 35 and $30 \%$ lower than of low-N plants in the 14- and 28-day clipped plants, respectively; however these differences were not significant. Carbohydrate content in roots, stubble and shoots of 28-day-old plants was some $25 \%$ lower than in 14-day-old plants. The effect of the $\mathrm{N}$ treatments on carbohydrate level was more pronounced in the roots than in the shoots or the stubble.

Table 1. Mean percent carbohydrates, total-N and nitrate-N in the shoots, stubble and roots of 'Common' Rhodes grass grown under different clipping and nitrogen treatments.

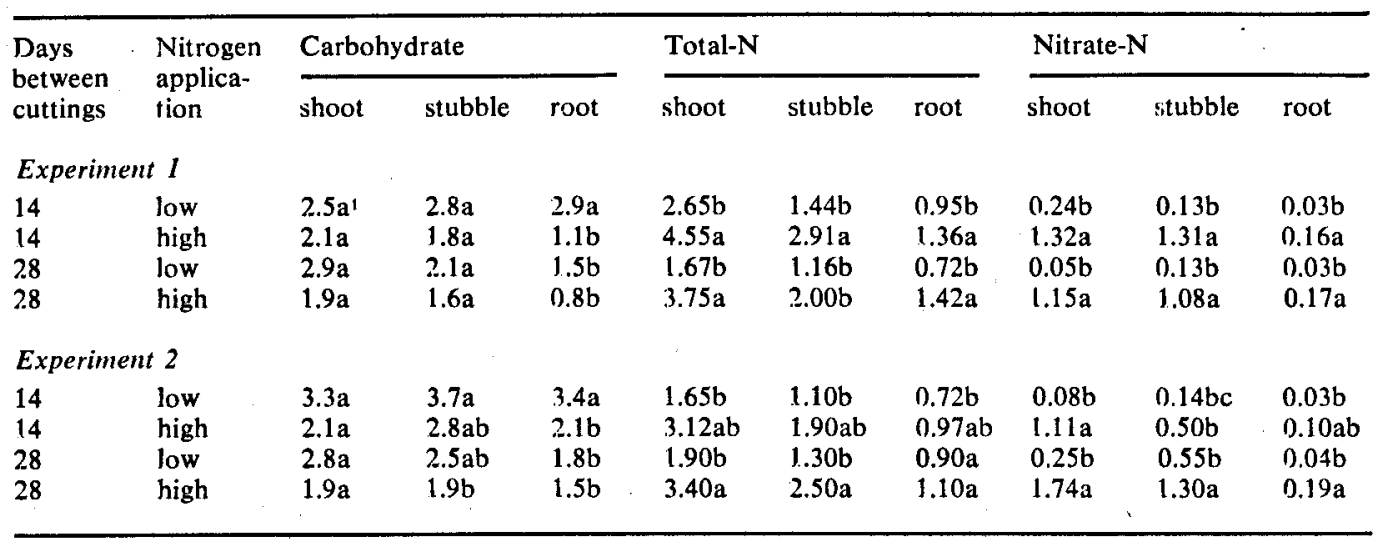

1 For each experiment means within a column followed by the same letter are not significantly different at 0.05 probability level.

Table 2. The effect of clipping and nitrogen application on the average amount of etiolated growth of 'Common' Rhodes grass.

\begin{tabular}{lll}
\hline $\begin{array}{l}\text { Days } \\
\text { between } \\
\text { cuttings }\end{array}$ & $\begin{array}{l}\text { Nitrogen } \\
\text { application }\end{array}$ & $\begin{array}{l}\text { Average dry weight } \\
(\mathrm{mg} / \text { pot })\end{array}$ \\
\end{tabular}

\section{Experiment 1}

$\begin{array}{rlr}14 & \text { low } & 423 \\ 14 & \text { high } & 206 \\ 28 & \text { low } & 132 \\ 28 & \text { high } & 56\end{array}$

\section{Experiment 2}

\begin{tabular}{llr}
14 & low & 502 \\
14 & high & 302 \\
28 & low & 123 \\
28 & high & 62 \\
\hline
\end{tabular}




\section{Etiolated growth}

The average amount of etiolated growth following the cutting of plants previously clipped at 14-day intervals was about 4 times higher than that of plants clipped every 28 days. Low- $\mathrm{N}$ plants produced at an average about twice higher the amount of etiolated growth than high- $\mathrm{N}$ plants (Table 2). That produced by plants clipped every 28 days was very small and of considerable variability within replications. This caused the lack of statistical significance of the difference in the amount of etiolated growth between low- and high-N plants.

The amount of etiolated growth and carbohydrate level of roots and of stubble were significantly correlated ( $r=0.807^{* *}$ and $0.700^{* *}, \mathrm{n}=24$, respectively) whereas etiolated growth and carbohydrate level of shoots were not associated. Thus the level of reserve carbohydrate in the roots and in the stubble which were available for intial regrowth was a rather good estimate of the amount of etiolated growth.

Etiolated growth originated only from the elongation of tillers present at the time of cutting. Considering this growth as the independent variable, a trend of linear increase of the percentage of regrowing tillers with the amount of etiolated growth was found up to about $200 \mathrm{mg}$ per pot after which a further increase of etiolated growth resulted in a fairly constant percentage of regrowing tillers (Fig. 1).

\section{Total- $N$ and nitrate- $N$ content}

The total-N content of shoots was higher than that of stubble and in turn was higher than that of roots (Table 1). The application of the high rate of $\mathbf{N}$ increased this content about $90 \%$ compared with the low rate of $\mathrm{N}$ in the shoots and stubble. Different clipping intervals did not consistently affect the total- $\mathrm{N}$ content of the herbage. However the content of organic nitrogen decreased consistently with longer clipping interval, as was expected.

The range of values of nitrate- $\mathrm{N}$ was always higher in the shoots and in the stubble compared with the roots (Table 1). The application of the high rate of $\mathrm{N}$ increased the average nitrate content of the shoots about 10 times and that of the stubble about 5 times compared with the low rate of $\mathrm{N}$ application. The average content in low- $\mathrm{N}$ herbage was $0.20 \%$ nitrate- $\mathrm{N}$ (or $12 \%$ of total $\mathrm{N}$ ), whereas that of high- $\mathrm{N}$ herbage averaged $1.43 \%$ nitrate- $\mathrm{N}$ (or $47 \%$ of total $\mathrm{N}$ ). Different clipping intervals did not consistently affect the nitrate content of the shoots and the stubble.

The nitrate content of shoots, stubble and roots was negatively correlated with the carbohydrate level of these fractions $\left(r=-0.613^{*},-0.693^{*}\right.$ and $-0.586^{*}, n=24$, respectively). The nitrate content of the roots was also negatively correlated with the amount of etiolated growth made in darkness $\left(r=-0.591^{*}\right)$.

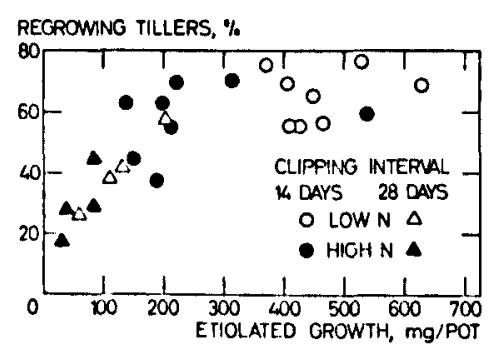

Fig. 1. Relationship between the amount of etiolated growth and percentage regrowing tillers in darkness following different cutting and nitrogen treatments of 'Common' Rhodes grass. Each dot represents the mean of 5 replicates. 
INFLUENCE OF DEFOLIATION AND NITROGEN ON REGROWTH OF RHODES GRASS. 2

\section{Discussion}

The values recorded for non-structural carbohydrates at the time of harvest were generally low, i.e. less than $3.7 \%$, and were of the same order as those recorded for summer-growing grasses (Weinmann, 1940; Barnes, 1960; Catchpoole, 1965; Humphreys and Robinson, 1966). In earlier work values were reported of non-structural carbohydrates of roots from field-grown Rhodes grass in mid summer which did not exceed 3\% (Dovrat and Cohen, 1970). Similarly to the here reported pot experiments the Rhodes grass plants were well supplied with moisture and nutrients and grew under temperature conditions optimal for photosynthesis (Murata et al., 1965). Thus the overall low carbohydrate level seems concomitant with the growing conditions favourable for rapid growth at least in cool-season grasses (Alberda, 1965; Brown and Blaser, 1965; Deinum, 1966).

Nitrogen availability and defoliation are both factors which affect the growth of herbaceous perennials and consequently influence the balance of carbohydrate accumulation. Data on dry-matter production, which were reported in our previous paper, showed that more shoot and less root dry matter was produced following high-N compared with low- $\mathrm{N}$ application. However the combination of high- $\mathrm{N}$ application with the long recovery period after cutting in our experiments was conducive to minimum carbohydrate level in shoots, stubble and roots (Table 1), to low yield of etiolated growth (Table 2), to diminishing the number of regrowing tillers in darkness (Fig. 1) and to decreasing the persistence of tillers (Dovrat et al., 1971). Still the total herbage yields were greater following 28-day compared with 14-day intervals between cuttings, measured over the entire experimental periods of 56 days each.

It can be assumed that moisture, temperature and light intensity were available in such quantities so as to secure maximum dry-matter production provided sufficient $N$ was applied in addition to the application of other essential nutrients. The total- $N$ and nitrate concentration of the plant fractions after the low- $\mathrm{N}$ application were considerably lower than those following the high- $\mathrm{N}$ application. That dry-matter production was limited because of the low-N supply is also clearly apparent from the relatively small portion of nitrate of the total- $N$ concentration (Table 1). Similar relationships were reported by Alberda (1965) and van Burg (1966).

A number of workers arbitrarily divide the time period between cuttings into: (1) initial regrowth - its rate mainly dependent of the amount of available carbohydrate which is accumulated during the pre-cutting period, and (2) subsequent growth - its rate mainly dependent of photosynthesis. If the parameter of initial regrowth is substituted for our data of the average amount of etiolated growth, or the average carbohydrate level of roots, then the results showed that high- $\mathrm{N}$ application reduced carbohydrate accumulation during the pre-cutting period more than low- $\mathrm{N}$ application. The inverse relationship which was found between the nitrate content of plant fractions and the carbohydrate level is in agreement with findings of Alberda (1965), Nowakowski and Cunningham (1965), van Burrg (1966) and Deinum (1966) working with cool-season grasses. From this we can conclude, supported by visual observations, that the initial regrowth in light of the high-N plants was smaller than of the low-N plants.

Kipnis (unpublished) found that the rate of decrease of the carbohydrate level in the stubble and roots of Rhodes grass fertilized with a high rate of $\mathrm{N}$, immediately following a recovery period of 28 days, was slower than that following a recovery period of 14 days. However, during this period of initial regrowth the carbohydrate level of 28 day-cut plants decreased to a lower minimum than that of 14-day-cut plants. Our data 
indicate that during the period of subsequent growth less carbohydrate was accumulated in 28-day-old plants than in 14-day-old plants, and in high- $\mathrm{N}$ less than in low-N plants. It should be noted, however, that these different carbohydrate levels little affected current dry-matter yields.

Thus it seems evident that Rhodes grass has a limited capacity to accumulate reserve materials when grown under conditions which favour rapid growth. This conclusion is supported by the fact that overall differences of carbohydrate level between shoots, stubble and roots were relatively small.

The results reported in the previous and present paper suggest that the regrowth of Rhodes grass and possibly also of other tropical grasses, is more dependent on tiller capacity and on tiller morphology than on carbohydrate reserves.

\section{Acknowledgment}

We acknowledge the kind assistance of Dr B. D. E. Gaillard, Department of Animal Physiology, Agricultural University, Wageningen, for carrying out exploratory chromatographical analyses and for her guidance in methods of carbohydrate determination.

\section{References}

Alberda, Th., 1965. The influence of temperature, light intensity and nitrate concentration on drymatter production and chemical composition of Lolium perenne L. Neth. J. agric. Sci. 13: $335-360$.

Alberda, Th., 1966. The influence of reserve substances on dry-matter production after defoliation. Proc. I0th Int. Grassld Congr. (Helsinki) 140-147.

Barnes, D. L., 1960. Growth and management studies on Sabi panicum and star grass. Rhodesia agric. J. 57: $399-411,451-457$.

Blaser, R. E., R. H. Brown \& H. T. Bryant, 1966. The relationship between carbohydrate accumulation and growth of grasses under different microclimates. Proc. 10th Int. Grassld Congr. (Helsinki) $147-150$.

Bosman, M. S. M., 1953. De bepaling van oplosbare suikers in gras. Meded. Centr. Inst. landbouwk. Onderz. 3: $1-5$.

Brown, R. H. \& R. E. Blaser, 1965. Relationships between reserve carbohydrate accumulation and growth rate in orchardgrass and tall fescue. Crop Sci. 5: 577-582.

Burg, P. F. J. van, 1966. Nitrate as an indicator of the nitrogen-nutrition status of grass. Proc. 10th Int. Grassld Congr. (Helsinki) 267-272.

Catchpoole, V. R., 1965. Laboratory ensilage of Setaria sphacelata (Nandi) and Chloris gayana (CPI 16144). Austr. J. agric. Res. 16: 391-402.

Davidson, J. L. \& F. L. Milthorpe, 1965. Growth of cocksfoot at different temperatures. Ann. Bot. 29: $407-418$.

Davidson, J. L. \& F. L. Milthorpe, 1966. The effect of defoliation on the carbon balance in Dactylis glomerata. Ann. Bot. 30: 185-198.

Deinum, B., 1966. Climate, nitrogen and grass. Meded. LandbHogesch. Wageningen 66-11; pp. 91.

Deys, W. B., 1961. De bepaling van totaal-stikstof in gewasmonsters, inclusief nitraatstikstof. Jaarb. Inst. biol. scheik. Onderz. LandbGewass.: 89-91.

Dovrat, A. \& Y. Cohen, 1970. Regrowth potential of Rhodes grass (Chloris gayana Kunth) as affected by nitrogen and defoliation. Proc. 1lth Int. Grassld Congr. (Surfers Paradise) 552-554.

Dovrat, A., J. G. P. Dirven \& B. Deinum, 1971. The influence of defoliation and nitrogen on the regrowth of Rhodes grass (Chloris gayana Kunth). 1. Dry-matter production and tillering. Neth. J. agric. Sci. 19: 94-101.

Humphreys, L. R. \& A. R. Robinson, 1966. Subtropical grass growth. I. Relationship between carbohydrate accumulation and leaf area in growth. Qd J. agric. Anim. Sci. 23: 211-259.

Hunter, R. A., B. L. McIntyre \& R. J. Mcllroy, 1970. Water-soluble carbohydrates of tropical pasture grasses and legumes. J. Sci. Fd Agric. 21: 400-405. 
Murata, Y., J. Iyama \& T. Honma, 1965. Studies on the photosynthesis of forage crops. 4. Influence of air temperature upon the photosynthesis and respiration of alfalfa and several southern-type forage grasses. Proc. Crop Sci. Soc. Japan 34: 154-158.

Nowakowski, T. Z. \& R. K. Cunningham, 1965. Nitrogen fractions and soluble carbohydrates in Italian ryegrass. II. Effects of light intensity, form and level of nitrogen. J. Sci. Fd Agric. 17: 145-150.

Plank, J. E. van der, 1936. The estimation of sugars in the leaf of mangold (Beta vulgaris). Biochem J. 30: $457-483$.

Smith, Dale, G. M. Paulsen \& C. A. Raguse, 1964. Extraction of total available carbohydrate from grass and legume tissue. Pl. Physiol. 39: 960-962.

Weinmann, H., 1940. Storage of root reserves in Rhodes grass. Pl. Physiol. 15: 467-484. 